\title{
Role of Godrej Mangroves in Climate Change Mitigation through Carbon Sequestration
}

\author{
Hemant Karkhanis, Sanjeev Pednekar, Tejashree Joshi
}

Hemant Karkhanis is M.Sc. Entomology (Zoology), Working in Godrej as Associate Manager in Mangrove Conservation Project since 11 years. He has 16 years research experience in mangrove conservation and insect biodiversity. Email: hok@godrej.com (Author for Correspondence)

Tejashree Joshi is BE in Environmental Engineering. Working in Godrej as Associate GM in Environmental Engineering Services since 17 years. She has 19 years experience in Environmental Engineering, Environmental Projects and Sustainability.

Sanjiv Pednekar is M.Sc. Environmental Sciences, Working in Godrej as Sr. Manager in Environmental Engineering Services since 11 years. He has 25 years experience in Envirolegal, Impact Assessment, Environmental Monitoring and Solid and Hazardous Waste Management.

\begin{abstract}
Godrej and Boyce Mfg. Co. Ltd. is conserving thousands of acres of mangrove forest along the western bank of Thane Creek (19 $03^{\prime} 31.12^{\prime \prime} N, 72^{\circ} 56^{\prime} 31.54^{\prime \prime} E$ to $19^{\circ} 06^{\prime} 31.43^{\prime \prime} N$ to $72^{\circ} 56^{\prime} 31.54^{\prime \prime} E$ ) since the decade of 1940s. In this rich biodiverse forest, we have recorded 16 species of mangrove and mangrove associated plants. These forests provide ecosystem services like prevention of coastal erosion, habitat for wildlife, livelihoods for local fisherfolk, research and education avenue for academia and regulation of local climate. This paper explains material and methodology used to measure sequestered carbon using data of past 3 years. Annually this forest sequesters 6 lakh tons of $\mathrm{CO}_{2}$ its potential annual increment value is around 50,000 tons of equivalent $\mathrm{CO}_{2}$. This carbon sequestration service is very valuable considering high emission of $\mathrm{CO}_{2}$ in the Mumbai Metropolitan Region and its impact on climate change. The paper also highlights importance of this project to the society and need to sensitize stakeholders for the mangrove conservation.
\end{abstract}

Key Words : mangrove ecosystem, Thane creek, ecosystem services, carbon sequestration, climate change

\section{Introduction}

The term mangrove is used in broad sense to refer to the highly adapted salt tolerant angiosperm plants occurring in tropical and subtropical marine coastal environments and along the banks of estuaries between lat. $30^{\circ} \mathrm{N}$ and $30^{\circ} \mathrm{S}$. In India 65 mangrove species belonging to 31 families have been recorded. Maharashtra has about $6.41 \%\left(304 \mathrm{~km}^{2}\right)$ of the total mangrove areas $\left(4,740 \mathrm{~km}^{2}\right)$ in India (assessment by the Forest survey of India, 2017).

Mangroves form highly productive ecosystem, supporting a wide variety of organisms including commercial fishery. They not only provide wood for different purposes but also give many important products such as honey, medicines etc. It has been observed that mangroves protect the shore from storms, hurricanes, tsunamis, etc. (CAB of forestry
Abstract, 1990). Mangroves supply food to marine communities via detritus food chain starting from leaf litter. The mangrove ecosystems provide a habitat for commercially important marine organisms like molluscs, prawns, crabs, fishes and act as feeding grounds for them and their juveniles. Studies have illustrated decline in fishery on loss of mangroves (Deshmukh, 1990). The mangrove swamps are known to act as natural sewage treatment plant, when conditions are favorable and the sewage is in reasonable quantity. These days, there is growing awareness regarding importance of mangroves and attempts are being made to conserve mangrove ecosystems. However, mangroves suffer damage through various anthropogenic activities like cutting for firewood, construction activities, timber reclamation, sand mining, dumping etc, animal grazing, by molluscan, insect pests, etc.

Thane creek (Long. $72^{\circ} .55^{\prime \prime} \mathrm{E}$ to $73^{\circ} .00^{\prime \prime} \mathrm{E}$ and Lat. 
$19^{\circ} .00 \mathrm{~N}$ to $19^{\circ} .15^{\prime \prime} \mathrm{N}$ ) is important coastal ecosystem near Mumbai of which Godrej and Boyce Mfg. Co. Ltd. is conserving almost 2000 acres of mangrove forest along western bank of Thane Creek $\left(19^{\circ} 03^{\prime} 31.12^{\prime \prime} \mathrm{N}, 72^{\circ} 56^{\prime} 31.54^{\prime \prime} \mathrm{E}\right.$ to $19^{\circ} 06^{\prime} 31.43^{\prime \prime} \mathrm{N}$ to $72^{\circ} 56^{\prime} 31.54^{\prime \prime}$ E) since the decade of 1940s. Thane creek extends approximately $26 \mathrm{~km}$ inside from the Arabian Sea and meets Ulhas river estuary by a minor connection near Thane city. As the riverine flow is less, the creek is tide dominated and experiences high salinity throughout the year except monsoon. However, due to growing urbanization in Thane- Mumbai region the creek receives significant quantity of fresh water in form of sewage. Thane creek's mangrove ecosystem has luxuriant mangroves along their banks. In past few decades, Thane creek ecosystem has been extensively studied for various aspects such as hydrology, sedimentology, mangroves, benthos, plankton, fishery and carbon footprints etc. (Deshmukh, 1990). Due to extensive urbanization and industrialization around Thane creek, this ecosystem is subjected to various damaging factors. Solid waste dumping, reclamation, pollution, cutting for the fuel are the main threats to mangroves in this region. To conserve mangrove along Thane creek, which is in-between Kanjur and Ghatkopar, Godrej is taking enormous efforts by implementing various activities focused on three pillars.

1) Education and awareness

2) Research

3) In-situ conservation of mangroves and development of eco-friendly infrastructure

Mumbai is one of the India's most polluted city as it experiences huge urbanization and very high levels of air pollution as a consequence. Mangroves along Mumbai act as green lungs of Mumbai and absorbs huge amount of $\mathrm{CO}_{2}$ in their body stock in the form of cellulose. In Godrej mangroves, we are measuring this fixed $\mathrm{CO}_{2}$ in the form of $\mathrm{C}$ to understand the role played by mangroves in reducing Green House Gases (GHG) and in reducing pollution in the Mumbai Metropolitan Region.

\section{Materials and Methods}

The purpose of this study was to estimate the total carbon stock in the mangrove forest at Godrej, Vikhroli. Specifically, it aimed to :

1) Determine the biomass and carbon density in the aboveground pools of the mangrove stands in the study area

2) Assess the amount of carbon sequestered in the soil.

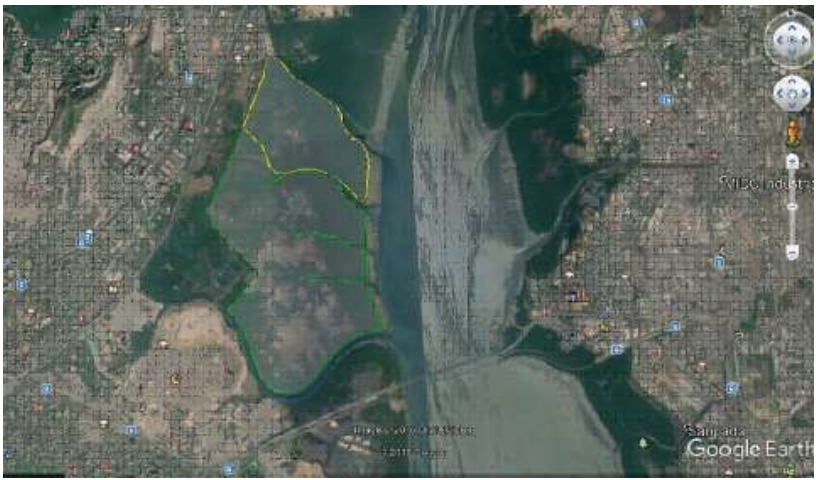

Photo 1 : Godrej Mangrove area along Thane creekLocations of sample collection. Area with yellow boundary- GEB, with green boundary- SPGF

The area selected for the study consists of mangrove forest located at Vikhroli, Mumbai, Maharashtra and under the control of Godrej and Boyce Mfg. Co. Ltd (G\&B) and Soonabai Pirojsha Godrej Foundation (SPGF). Both of these areas are separated by a canal or creeklet which leads to Godrej jetty area (Photo1)

As far as the land cover of the study area is concerned, it includes a mixed type of classes ranging from dense vegetation, moderate vegetation, grassland area, mud flats, water body and open area. To study the land use and land cover class of study area, Remote Sensing technique has been employed from RESOURCESAT - 2, LISS IV F MX (CEED). The following are the five different land use classes obtained from the analysis :

\section{Dense vegetation}

This includes thick vegetation cover with different types of trees or plants covering land in an undefined manner. Many trees grow over only a small part of land with a dense canopy cover. The dense vegetation cover in the study area is dominated by the thick canopy cover of mangrove trees.

\section{Moderate vegetation}

This is a land use categorized under vegetation cover which represented by a land category with open type of vegetation.

This category in the study area includes mangrove trees having an open canopy cover.

\section{Grassland}

These are the areas of natural grass along with other vegetation, predominantly grasses and forbes. 


\section{Mud-flats}

These are categorized under coastal wetlands that are formed when mud is deposited by tides or rivers. They are found in sheltered areas such as bays, bayous, lagoons, and estuaries. Mudflats may be viewed geologically as exposed layers of bay mud, resulting from deposition of estuarine silts, clays and marine animal detritus.

\section{Open area}

The open area within the study area comprises of open land areas with no angiosperm cover. It only had cryptogamic vegetation, mostly of algae.

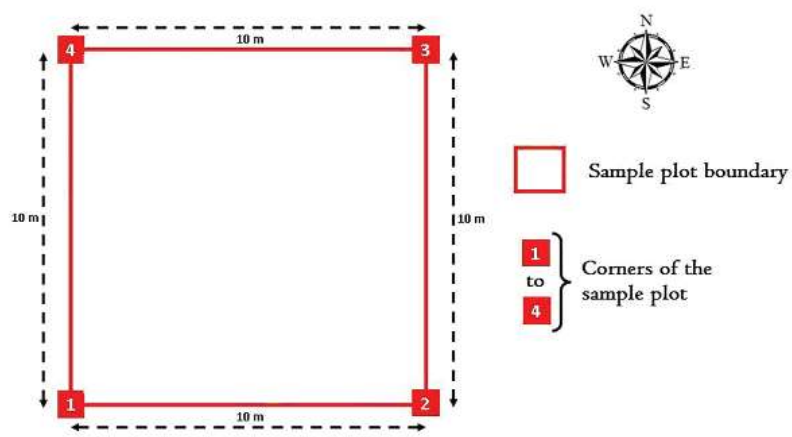

Figure 1. Layout of sample plot

For deriving the number of permanent sample plots required to estimate the carbon stock present within the project area, it was necessary to collect a standard deviation of carbon stock of each stratum. This was done through a pilot sampling carried out in each stratum. Two sample plots in each stratum were visited during the pilot sampling.

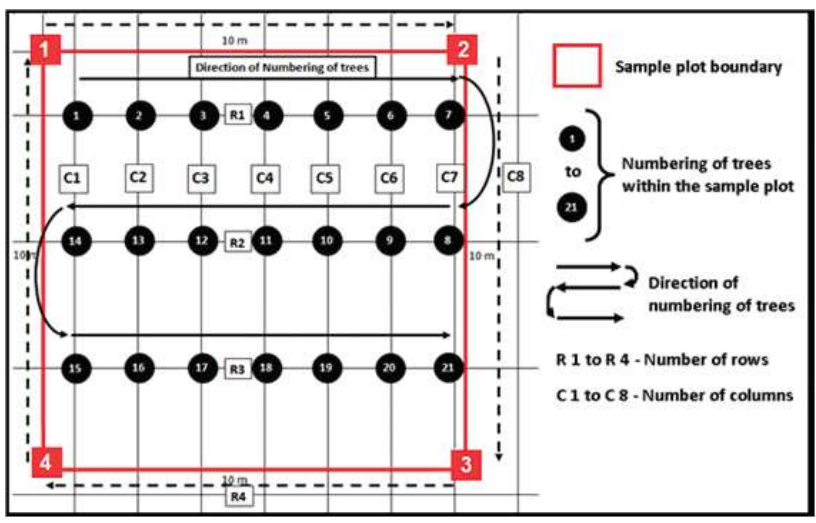

Figure 2. Numbering of trees within the sample plot
Table 1: Number of sample plots laid in each stratum

\begin{tabular}{|c|l|c|}
\hline Sr. No. & Stratum & No. of plots \\
\hline $\mathbf{1}$ & Dense vegetation & 3 \\
\hline $\mathbf{2}$ & Moderate vegetation & 7 \\
\hline $\mathbf{3}$ & Grasslands & 4 \\
\hline $\mathbf{4}$ & Open area & 2 \\
\hline & Total & 16 \\
\hline
\end{tabular}

\section{Numbering the trees within the plot}

Trees were numbered from the corner of the sample plot. The tree nearest to the first corner was numbered as 1st tree. Numbering was then proceeded along the row towards the other corner of the sample plot. At the end of this, next row was covered and then starting corner of the plot was covered to end tree marking. Numbering of the trees was continued in zigzag fashion (refer Fig. 2) If there was a gap or a dead tree, its details were noted in the fieldnotes. Trees in research plots were numbered with weather resistant, white/yellow paint.

A calibrated measuring tape was used to measure the GBH of trees in sample plot. Tree height was determined using graduated bamboo sticks.

The permanent sample plot boundary was recorded using GARMIN eTrex VISTA Cx.

The carbon pools that can be considered for carbon stock estimation are defined as follows:

Above ground biomass (AGB): This pool includes all living biomass above the soil including stem, stump, branches, bark, seeds, and foliage. Where forest under storey is a relatively small component of the above-ground biomass carbon pool, this may be ignored so long as the methodology is used consistently throughout the inventory time series.

Below ground biomass (BGB): This pool includes all living biomass of live roots. Fine roots under, say, $2 \mathrm{~mm}$ diameter may be excluded as they often cannot be distinguished from soil organic matter or litter.

Dead wood (DW): All non-living woody biomass not contained in the litter, either standing, lying on the ground, or in the soil. This includes wood lying on the surface, dead roots, and stumps (usually defined as having a diameter of at least $10 \mathrm{~cm}$ ).

Litter: All non-living biomass with a smaller diameter than that used for dead wood (say, $10 \mathrm{~cm}$ ), lying dead, in various states of decomposition above the 
mineral or organic soil. This includes the litter, fumic, and humic layers. Live fine roots (of less than the diameter limit for below-ground biomass, say $2 \mathrm{~mm}$ ) may be included here.

Soil organic carbon (SOC): Includes organic carbon in mineral soils to a specified depth chosen by the country and applied consistently through the time series. Live fine roots (of less than the chosen diameter limit for below-ground biomass) to $30 \mathrm{~cm}$ depth may be included here.

The pools selected for the present study were aboveground live trees, dead trees, drowned wood, belowground plant carbon, and soil carbon. These five pools likely comprise $>95 \%$ of the true ecosystem carbon stock of mangroves.

The carbon stock estimation of trees i.e. for the above ground biomass and below ground biomass carbon pool was done using the approved A/R CDM methodological tool: "Estimation of carbon stocks and change in carbon stocks of trees and shrubs in $A / R C D M$ project activities" 03.0.0.

Three methods have been described in the tool. They are Stock Change method, increment method and baseline default method. In our study, Stock change method was used. In this method carbon stock in trees within the project boundary is estimated annually since 2013 at successive points of time. Change in carbon stock in trees between two successive points of time is calculated as the difference between the two estimated stocks.

\section{Total carbon stock}

The total carbon stock was estimated by adding all the five components of the carbon pool.

The equation for total carbon stock for a given project area is as follows:

$$
\mathrm{C}_{\mathrm{PROJECT}, \mathrm{t}}=\mathrm{C}_{\mathrm{TREE} . \mathrm{t}}+\mathrm{C}_{\mathrm{DW}, \mathrm{t}}+\mathrm{C}_{\mathrm{LL}, \mathrm{t}}+\mathrm{C}_{\mathrm{SOC}, \mathrm{t}}
$$

Where,

$C_{P R O J E C T, t}:$ Change in the carbon stocks in project, occur- ring in the selected carbon pools, in $\mathrm{t}$; $\mathrm{CO} 2-e$

$C_{\text {TREE }}$ : Change in carbon stock in tree biomass in project in year $\mathrm{t}$, as estimated in the "Estimation of carbon stocks and change in carbon stocks of trees and shrubs in CDM project activities"; $t$ CO2-e

$C_{D W, t}$ :Change in carbon stock in dead wood in project in year $\mathrm{t}$, as estimated in the "Estimation of carbon stocks and change in carbon stocks in dead wood and litter A/R CDM project activities"; $t$ CO2-e

$C_{I I}$ :Change in carbon stock in litter in project in year $\mathrm{t}$, as estimated in the tool "Estimation of carbon stocks and change in carbon stocks in dead wood and litter in $A / R$ project activities"; $t$ CO2-e

$\mathrm{C}_{\mathrm{SOC}, \mathrm{t}}$ :Change in carbon stock in SOC in project, in year $t$; $t$ CO2-e

$t: 1,2,3, \ldots$ counted from the start of the project activity

\section{Results}

The Carbon stock in project area $\left(\mathrm{C}_{\text {PROIECT, }}\right)$ calculated using the equation mentioned in methods is given below (Table 2).

\section{Discussion}

The estimation of carbon sequestration by Godrej mangroves provided valuable insights to their ecosystem provided by them not just to Godrej campus but significant landscape of Eastern shoreline of Mumbai Metropolitan Region (MMR). The finding offers quantifiable reason for mangrove research to Godrej and Boyce considering the organization's carbon neutrality target. The same has been mentioned in the organization's documents such as Business Excellence Report and Sustainability Report.

Godrej and Boyce has discussed this research with the Mangrove Cell of Maharashtra Forest Department with a suggestion to conduct similar research on mangroves of MMR, and perhaps state of Maharashtra. This will help the State authorities to realise importance of mangroves and convince stakeholders through an awareness campaign.

Table 2 : Carbon stock in project area

\begin{tabular}{|l|l|l|l|l|l|}
\hline Project area & $\begin{array}{l}\mathrm{C}_{\text {TREE, }} \\
\text { tCO2e }\end{array}$ & $\begin{array}{l}\mathrm{C}_{\text {DW,t }} \\
\text { t CO2-e }\end{array}$ & $\begin{array}{l}\mathrm{C}_{\text {LI, }} \\
\text { t CO2-e }\end{array}$ & $\begin{array}{l}\mathrm{C}_{\text {SOC,t }} \\
\text { t CO2-e }\end{array}$ & $\begin{array}{l}\mathrm{C}_{\text {PROJECT,t }} \\
\text { t CO2-e }\end{array}$ \\
\hline G\&B & 66284 & 8423 & 46 & 97221 & 171976 \\
\hline SPGF & 141746 & 3938 & 21 & 279427 & 425134 \\
\hline Total & $\mathbf{2 0 8 0 3 0}$ & $\mathbf{1 2 3 6 1}$ & $\mathbf{6 7}$ & $\mathbf{3 7 6 6 4 8}$ & $\mathbf{5 9 7 1 1 0}$ \\
\hline
\end{tabular}




\section{Conclusion}

This study is first of its kind in the state of Maharashtra.

It highlighted remarkable contribution by a corporate house in mangrove conservation. The ecosystem services of carbon sequestration delivered by the Godrej mangroves benefit entire Mumbai Metropolitan Region which needs green lungs to absorb the Greenhouse Gases (GHGs) emitted by countless anthropogenic activates. Extrapolating the carbon sequestration services of Godrej mangroves to entire mangrove ecosystem of the Mumbai Metropolitan Region, this study makes clear case for wetland conservation for climate regulation.

\section{List of references}

CAB of forestry Abstract (1990). 041-08074 (Biological abstract). www.cabi.org

CEED, Study report- Carbon Sequestration in Godrej Mangroves at Vikhroli

Chauhan, S., and Saxena, A. (2013). Methodological Issues for Assessing Carbon Stock for REDD+ Project in India. The Energy and Resources Institute (TERI).

Deshmukh, S. V. (1990) Ecological study of mangroves in Bombay. Ph.D. Thesis, University of Mumbai

Gevaña, D. T., Pulhin, F. B., and Pampolina, N. M. (2008). Carbon stock assessment of a mangrove ecosystem in San Juan, Batangas. Journal of Environmental Science and Management, 11(1).

Golden Agri-Resources and SMART(2012) High Carbon Stock Forest Report http://

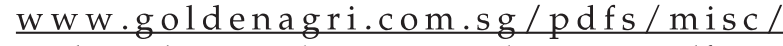
High Carbon Stock Forest Study Report.pdf

Kauffman, J. B., and Donato, D. C. (2012). Protocols for the measurement, monitoring and reporting of structure, biomass, and carbon stocks in mangrove forests. Paper 86, Center for International Forestry Research Bogor, Indonesia.

Kauffman, J. B., Heider, C., Cole, T. G., Dwire, K. A., and Donato, D. C. (2011). Ecosystem carbon stocks of Micronesian mangrove forests. Wetlands, 31(2), 343-352.

Komiyama, A., Ong, J. E., and Poungparn, S. (2008). Allometry, biomass, and productivity of mangrove forests : A review. Aquatic Botany, 89(2), 128-137.

Kathiresan, K. Methods of studying Mangroves, Centre of Advanced Study in Marine Biology Annamalai University

Kridiborworn, P., Chidthaisong, A., Towprayoon, S., and Tripetchkul, S. Mitigating greenhouse gas emissions through mangrove plantation and charcoal production.

https://www.researchgate.net/profile/ Sirintornthep_Towprayoon / publication / 267846409_Mitigating_greenhouse_gas_emissions_ through_mangrove_plantation_and_charcoal_ production/links/549408630cf2d50049e78db7.pdf

Murdiyarso, D., Donato, D., Kauffman, J. B., Kurnianto, S., Stidham, M., and Kanninen, M. (2009). Carbon storage in mangrove and peatland ecosystems: A preliminary account from plots in Indonesia. Working paper 48. Bogor Banat, Indonesia: Center for International Forestry Research. 35 p., 1-35.

Ponce-Hernandez, R., Koohafkan, P., and Antoine, J. (2004). Assessing carbon stocks and modelling winwin scenarios of carbon sequestration through land-use changes (Vol. 1). Food and Agriculture Org.

Shoch, D., Eaton, J., and Settelmyer, S. (2013). Project developer's guidebook to VCS REDD methodologies Version 2.0. Conservation International.

Sremongkontip, S., Hussin, Y. A., Groenindijk, L., and Detection, C. (2000). Detecting changes in the mangrove forests of Southern Thailand using remotely sensed data and GIS. International Archives of Photogrammetry and Remote Sensing, 33(B7), 567574.

Thinh P.T., Meinardi D. and Schmitt K. 2011. Monitoring of Mangrove Forests. Deutsche Gesellschaft für Internationale Zusammenarbeit (GIZ) GmbH, Management of Natural Resources in the Coastal Zone of Soc Trang Province, Viet Nam. Available from: http://daln.gov.vn/en/dl/document-library.html

Zerihun Getu, Gemedo Dale, Motuma Tafa, James Njogu, and Tesfaye Gonfa, (2011). Carbon stock assessment in different land uses for REDD+ Ethiopia. Practitioners field guide/manual. Yayu Forest Coffee Biosphere Reserve. pp 18. 